\title{
Coccidiosis in broiler chickens raised in the Araguaína region, State of Tocantins, Brazil
}

\author{
Coccidiose em frangos de corte criados na região de Araguaína, Estado do Tocantis, Brasil \\ Gustavo Andrade Toledo'; J Jefferson Douglas de Moura Almeida'; \\ Katyane de Sousa Almeida ${ }^{1}$; Fagner Luiz da Costa Freitas ${ }^{1 *}$
}

${ }^{1}$ Laboratório de Higiene e Saúde Pública, Escola de Medicina Veterinária e Zootecnia, Universidade Federal do Tocantins - UFT

Received October 25, 2010

Accepted November 29, 2010

\section{Resumo}

A eimeriose é responsável por causar graves problemas avícolas caracterizados, principalmente, por redução do ganho de peso e alteraçáo na conversão alimentar, gerando grandes perdas econômicas. O objetivo deste trabalho foi avaliar a epidemiologia da eimeriose em frangos de corte na região de Araguaína, Estado do Tocantins, Brasil. Amostras de cinco propriedades foram colhidas e encaminhadas ao Laboratório de Higiene e Saúde Pública da Escola de Medicina Veterinária e Zootecnia da Universidade Federal do Tocantins. Após análise parasitológica, comprovou-se que todas as propriedades avaliadas apresentaram positividade para espécies do gênero Eimeria, tendo 63,1\% dos galpóes positivos, sendo encontrados oocistos de E. maxima, E. acervulina, E. mitis e E. tenella. Conclui-se que todas as propriedades avaliadas, apresentaram positividade para quatro espécies do gênero Eimeria comprovando que as estratégias sanitárias adotadas nas criaçóes apresentam falhas que possibilitam a disseminação do patógeno nos lotes avícolas.

Palavras-chave: Eimeriose, frangos de corte, epidemiologia.

\begin{abstract}
Eimeriosis is responsible for causing serious problems in poultry, mainly characterized by reduced weight gain and abnormalities of food conversion efficiency, thereby causing great economic losses. The aim of this study was to evaluate the epidemiology of eimeriosis in broiler chickens in the Araguaina region, State of Tocantins, Brazil. Samples from five farm properties were collected and sent to the Hygiene and Public Health Laboratory, School of Veterinary Medicine and Zootechnics, Federal University of Tocantins. From the parasitological analysis, it was shown that all the properties examined were positive for Eimeria species. $63.1 \%$ of the sheds were positive, with findings of oocysts of E. maxima, E. acervulina, E. mitis and E. tenella. It was concluded that all properties evaluated were positive for four species of the genus Eimeria, thus demonstrating that the sanitary strategies followed in poultry rearing had flaws that allowed pathogens to spread in poultry pens.
\end{abstract}

Keywords: Eimeriosis, broilers, epidemiology.

\section{Introduction}

The protozoan Eimeria spp. belongs to the phylum Apicomplexa, order Coccidia and family Eimeriidae, and is characterized by having an oocyst that, as a form of resistance, contains four sporocysts that each have two sporozoites (REY, 2005). This parasite causes eimeriosis or coccidiosis, an illness that is a serious animal health problem, given the many organ abnormalities that it provokes in several domestic and wild species.

The growing demand for meat on the Brazilian and foreign markets has caused increased purchases of medications and vaccines by poultry-raising farms, with the aim of reducing the mortality rate

\footnotetext{
${ }^{*}$ Corresponding author: Fagner Luiz da Costa

Laboratório de Higiene e Saúde Pública, Escola de Medicina Veterinária e

Zootecnia, Universidade Federal do Tocantins - UFT, BR153, Km 112,

Zona Rural, CP 132, CEP 77804-970, Araguaína - TO, Brazil;

e-mail: fagnerfreitas@uft.edu.br
}

among the birds. However, misuse of anticoccidian drugs together with failures of health management have contributed towards the emergence of resistant strains, which means that Eimeria spp. continues to be present in poultry farms. Kessler et al. (1979) stated that this disease is an impediment to poultry development because of its easy transmission and the difficulties in controlling it. Birds become infected through ingesting sporulated oocysts of Eimeria spp. (NORTON; CHARD, 1983), which are introduced into poultry sheds through transportation on footwear, clothes, people's skin, equipment, rodents, insects, etc (KAWAZOE, 2000).

A variety of factors relating to the parasite, host and environment may interfere with the biology of the parasite, such as: pathogenicity of the oocyst, parasite specificity for a given parasitism location, number of generations of merogony, biotic potential of the parasite, prepatent and patent period for oocyst elimination, 
host age and immunity, diet, length of gestation, erroneous and indiscriminate use of antiparasitic medications and, especially, associated infections (FAYER, 1980). Currently, seven species of Eimeria spp. that parasitize broiler chickens are recognized: E. tenella in the ceca, E. maxima in the entire small intestine, E. mitis in the duodenum and jejunum, E. acervulina in the anterior region of the small intestine, E. necatrix in the small intestine and ceca and E. praecox and E. brunetti in the ileum and colon.

Coccidiosis affects the host in several ways, depending on the tissue preference of the parasite involved and the number of oocysts ingested in the initial infection (CONWAY et al., 1993). In Brazil, the first case eimeriosis in poultry was reported by Reis and Nóbrega (1936) in the State of São Paulo, and E. acervulina, E. maxima and E. tenella were among the species described. These species are currently monitored in poultry farms by means of an intestinal lesion score. In a general manner, the intestinal species of the genus Eimeria are responsible for severe enteritis that has a negative repercussion on the host's nutrient absorption and zootechnical performance. They may cause death, depending on the animal's state of health and the infecting dose (FREITAS et al., 2008b). The lesions caused by intestinal eimeriosis five rise to disorders of nutrient absorption, thereby triggering changes to carbohydrate, protein, lipid and macro and micronutrient metabolism (TURK et al., 1982; FREITAS et al., 2008a). However, the mechanisms involved in these changes are not totally clear with regard to the post-infection period within which they occur and the repercussion of this infection on the host's weight gain.

The bloody enteritis caused by the intestinal species of Eimeria in chickens also impairs the absorption of electrolytes (TURK, 1973), calcium and iron (TURK, 1981) and magnesium (TURK et al., 1982). This reduction in plasma electrolytes, in association with blood losses, affects the compensatory hematopoiesis (NATT; HERRICK, 1955), such that low hematocrit and low hemoglobin concentrations are observed (TURK, 1986).

The diagnostic method routinely used in poultry farms is centered on the scores and characteristics of the intestinal lesions caused by three species (E. acervulina, E. maxima and E. tenella) that are considered important in poultry rearing. These species have been shown to cause intestinal lesions and organic changes. However, scoring for the lesions needs to be done in conjunction with parasitological examination of the feces from the chickens' litter, so that no diagnostic errors are made. Studies developed in poultry enterprises should cover all species of Eimeria, given that the non-diagnosed species are also responsible for poultry farming losses. In addition, epidemiological studies need to be conducted in order to ascertain the regional factors that predispose towards eimeriosis, with the aim of undertaking rational control, thereby minimizing the producers' costs. The aim of the present study was to diagnose species of the genus Eimeria and assess risk factors in the Araguaína region, in order to contribute towards gauging the magnitude of the illness better.

\section{Material and Methods}

This study was conducted in the municipality of Araguaína between August 2009 and June 2010. The poultry pens were evaluated according to their constructed areas: small size (area less than $300 \mathrm{~m}^{2}$ ), medium size (area between 300 and $1000 \mathrm{~m}^{2}$ ) and large size (area greater than $1000 \mathrm{~m}^{2}$ ). All the sheds visited contained broiler chickens over the age of 15 days.

Feces were collected directly from the floors of the poultry pens by walking three times the greatest length of the shed to obtain three samples per shed that were composed of recently eliminated feces. The first sample was collected by zigzagging to the other extremity of the installation, starting from the right side of the shed. For the second sample, the path followed was the inverse of that of the first sample, i.e. starting from the left side of the shed. The third sample was collected from between the eating and drinking troughs of the shed. The material collected was packed into $500 \mathrm{~mL}$ flasks containing $175 \mathrm{~mL}$ of $2.5 \%$ potassium dichromate, making up the volume in the flask to reach $350 \mathrm{~mL}$, in accordance with the technique used by Franco (1993). The samples collected were sent to the Hygiene and Public Health Laboratory, School of Veterinary Medicine and Zootechnics, Federal University of Tocantins, and were subjected to a process of purification and concentration of the oocysts in saturated saline solution. The oocysts were isolated from the positive samples and 30 oocysts underwent micrometric evaluation using a micrometric eyepiece coupled to a Bioval optical microscope.

During the visits to the farm properties, epidemiological questionnaires were applied with the aim of ascertaining the characteristics of the poultry rearing and consequently the health management used. Data relating to the chicken breed, composition of the chicken litter, interval between changes of litter and the use of vaccines and medications were obtained.

To calculate the frequency of infection, the number of positive sheds was divided by the number of sheds sampled. Descriptive statistical analysis was used, consisting of the absolute and relative distribution per shed and farm property.

\section{Results and Discussion}

The absence of current data relating to the economic losses caused by eimeriosis hinders assessment of the magnitude of its impact on production costs. All the farm properties evaluated in the present study were contaminated with species of the genus Eimeria, and $63.1 \%$ of the sheds were positive. Rice straw was the main component of the chicken litter used in these farms, and the mean interval between litter changes was 150 days in $60 \%$ of the properties. This study showed that the chicken raisers were concerned about controlling diseases of infectious origin, such as infectious bursal disease (Birnavirus), Marek's disease (Herpesvirus) and Newcastle disease (Paramyxovirus). All of these are known diseases that are controlled by means of vaccines; only one raiser showed lack of knowledge about the vaccines used in the farm properties (Table 1). Regarding the possible use of drugs in feed or water, it was observed that none of the individuals responsible for chicken rearing in these farms had any knowledge of this. Another risk factor observed in the farm properties was an evident lack of use of protective clothing among the individuals involved in managing the poultry, thus contributing to parasite spread between the different sheds within the property.

Oocysts of E. maxima, E. acervulina, E. mitis and E. tenella were found in $100 \%$ of the farm properties, and the morphometric data 
Table 1. General characteristics of health management used in the broiler chicken farm properties visited in the municipality of Araguaína, State of Tocantins, Brazil, 2010.

\begin{tabular}{|c|c|c|c|c|c|}
\hline $\begin{array}{l}\text { Management } \\
\text { characteristics }\end{array}$ & Farm 1 & Farm 2 & Farm 3 & Farm 4 & Farm 5 \\
\hline $\begin{array}{l}\text { Numbers of positive sheds/ } \\
\text { sheds evaluated }\end{array}$ & $2 / 2$ & $4 / 4$ & $7 / 10$ & $1 / 1$ & $2 / 2$ \\
\hline Chicken breed & Ross & Ross & Cobb & Cobb & Ross \\
\hline Shed area & $1500 \mathrm{~m}^{2}$ & $1650 \mathrm{~m}^{2}$ & $1320 \mathrm{~m}^{2}$ & $2200 \mathrm{~m}^{2}$ & $1200 \mathrm{~m}^{2}$ \\
\hline Chicken litter composition & Rice straw & $\begin{array}{l}\text { Rice straw and } \\
\text { wood shavings }\end{array}$ & Rice straw & Rice straw & Rice straw \\
\hline $\begin{array}{l}\text { Interval between } \\
\text { litter changes }\end{array}$ & 45 days & 45 days & 135 days & 135 days & 180 days \\
\hline Vaccines used & $\begin{array}{c}\text { Marek and } \\
\text { Gumboro }\end{array}$ & $\begin{array}{c}\text { Marek, Gumboro } \\
\text { and Newcastle }\end{array}$ & Gumboro & Unable to say & $\begin{array}{l}\text { Marek and } \\
\text { Gumboro }\end{array}$ \\
\hline
\end{tabular}

Table 2. Biometric characteristics of the oocysts and sporocysts of different species of the genus Eimeria that were isolated in the municipality of Araguaína, State of Tocantins, Brazil.

\begin{tabular}{|c|c|c|c|c|c|c|}
\hline \multirow[t]{2}{*}{ Species } & \multicolumn{2}{|c|}{ Oocyst $(\mu \mathrm{m})$} & \multirow{2}{*}{$\begin{array}{l}\text { Morphometric } \\
\text { index }\end{array}$} & \multicolumn{2}{|c|}{ Sporocyst $(\mu \mathbf{m})$} & \multirow{2}{*}{$\begin{array}{l}\text { Morphometric } \\
\text { index }\end{array}$} \\
\hline & Length & Width & & Length & Width & \\
\hline E. maxima & $35.4(29.1-44.9)$ & $22.4(14.3-24.3)$ & $1.66(1.2-2.8)$ & $14.0(9.7-19.4)$ & $8.3(7.2-9.7)$ & $1.70(1.3-2.3)$ \\
\hline E. tenella & $23.1(20.6-26.7)$ & $17.5(17.0-19.4)$ & $1.32(1.1-1.8)$ & $14.8(17.2-18.0)$ & $7.2(3.6-7.2)$ & $2.00(1.1-2.5)$ \\
\hline E. acervulina & $19.1(18.2-20.6)$ & $13.0(9.7-14.6)$ & $1.59(1.0-2.3)$ & $9.1(7.2-12.1)$ & $5.7(4.8-7.2)$ & $1.62(1.0-2.0)$ \\
\hline E. mitis & $16.7(14.5-17.0)$ & $13.4(12.1-14.6)$ & $1.23(1.1-1.4)$ & $11.5(7.2-14.6)$ & $6.5(4.8-7.3)$ & $1.69(1.0-2.0)$ \\
\hline
\end{tabular}

on these species are described in Table 2. E. brunetti, E. praecox and $E$. necatrix were not diagnosed on the farm properties in Araguaina. In the present study, the possibility that the oocysts encountered might have come from vaccine strains was rejected because the company that supplied chicks to the poultry farms in the region did not use vaccines against eimeriosis in its calendar for stock vaccination, and the same management was used by the farms that were investigated. In the municipality of Pará de Minas, State of Minas Gerais, ten field isolates of Eimeria were obtained, consisting of one of E. acervulina, three of E. mitis and six of $E$. praecox, thus showing occurrences of species other than those monitored by the poultry enterprises (COSTA, 2000). In a survey carried out in the region of Monte Alegre do Sul, State of São Paulo, in which parasitological examination of scrapings from the intestinal mucosa was used, taking into consideration the morphometric characteristics of the oocysts, six species were diagnosed: E. maxima, E. brunetti, E. tenella, E. acervulina, E. mitis and E. necatrix (TERRA et al., 2001). The high rate of positive findings in the present study was related to failures of health management. The high levels of contamination in the sheds were related to spreading of the protozoan within the farm property, given that the chicken litter was reused. This practice was justified in terms of the difficulty in acquiring materials to make up the chicken litter, with high prices charged for the raw materials, which made it a necessary practice in the region of Araguaina, in the State of Tocantins. It is important to emphasize that the great obstacle preventing control over eimeriosis relates to the mechanisms of resistance to drugs that are administered indiscriminately in feed. Thus, together with failure to disinfect the installations, contributes towards continuing presence of the parasite in the poultry and consequently in the environment.

\section{Conclusion}

All the farm properties evaluated were positive for four species of the genus Eimeria, with a high frequency of positive sheds, thus demonstrating that the health strategies used in chicken rearing presented failures that made it possible for the pathogen to spread between the poultry pens.

\section{References}

CONWAY, D. P. et al. Effects of different levels of oocyst inocula of Eimeria acervulina, E. tenella and E. maxima on plasma constituents, packed cell volume, lesion scores, and performance in chickens. Avian Diseases, v. 37, n. 1, p. 118-123, 1993. PMid:8452488. http://dx.doi. org/10.2307/1591464

COSTA, C. A. F. Caracterizaçáo biológica e estudo da variabilidade genética inter e intra-específica de algumas espécies de Eimeria de Gallus gallus em Minas Gerais - Brasil. 2000. 122 f. Tese (Doutorado em Ciências Biológicas)-Universidade Federal de Minas Gerais, Belo Horizonte.

FAYER, R. Epidemiology of protozoan infections: the coccidia. Veterinary Parasitology, v. 6, n. 1-3, p. 75-103, 1980. http://dx.doi. org/10.1016/0304-4017(80)90039-4

FRANCO, R. M. B. Levantamento de eimeriose em duas granjas de aves de postura da região de Campinas, São Paulo. Arquivo Brasileiro de Medicina Veterinária e Zootecnia, v. 45, n. 6, p. 557-571, 1993. 
FREITAS, F. L. C. et al. Lipid and glucose metabolism of broilers (Gallus gallus domesticus) experimentally infected with Eimeria acervulina Tyzzer, 1929 oocysts. Brazilian Journal of Poultry Science, v. 10, n. 3 , p. 157-162, 2008a.

FREITAS, F. L. C. et al. Alterações clínicas e patológicas em frangos de corte (Gallus gallus domesticus) infectados experimentalmente com oocistos esporulados de Eimeria acervulina Tyzzer, 1929. Revista Brasileira de Parasitologia Veterinária, v. 17, n. 1, p. 16-20, 2008 b.

KAWAZOE, U. Coccidiose. In: BERCHIERI JÚNIOR, A.; MACARI, M. Doenças das aves. Campinas: FACTA, 2000. p. 391-405.

KESSLER, R. H. et al. Ocorrência de Eimeria acervulina (TYZZER, 1929) em Gallus gallus domesticus no Rio Grande do Sul. Arquivos da Faculdade de Veterinária da Universidade Federal do Rio Grande do Sul, v. 7, n. 1, p. 105-119, 1979.

NATT, M. P.; HERRICK, C. A. The effect of cecal coccidiosis on the blood cells of the domestic fowl. Poultry Science, v. 34, n. 3, p. 1100-1106, 1955.

NORTON, C. C.; CHARD, M. J. The oocyst sporulation time of Eimeria species from the fowl. Parasitology, v. 86, n. 2, p. 193-198, 1983. http://dx.doi.org/10.1017/S0031182000050368
REIS, J.; NÓBREGA, P. Doenças das Aves. São Paulo: Instituto Biológico de São Paulo, 1936. 468 p.

REY, L. Parasitologia. Rio de Janeiro: Guanabara Koogan, 2005. 695 p.

TERRA, A. T. et al. Frequência de espécies do gênero Eimeria em frangos de cortes abatidos industrialmente no município de Monte Alegre do Sul, Estado de São Paulo. Revista Brasileira de Parasitologia Veterinária, v. 10, n. 2, p. 87-90, 2001.

TURK, D. E. Calcium absorption during coccidial infections in chicks. Poultry Science, v. 52, n. 3, p. 854-857, 1973. PMid:4754042

TURK, D. E. Coccidial infections and iron absorption.Poultry Science, v. 60, n. 2, p. 323-326, 1981. PMid:7267530

TURK, D. E. Macroelements in the circulation of coccidiosis infected chicks. Poultry Science,v.65, n.1, p.462-468, 1986.PMid:3703792

TURK, D. E.; GUNJI, D. S.; MOLITORIS, P. Coccidial infections and manganese absorption.Poultry Science, v.61, n. 12, p.2430-2434, 1982.PMid:7163120 